\title{
THE IMPACT OF A BUDDY SYSTEM ON THE SELF-CARE BEHAVIOURS OF WOMEN LIVING WITH HIVIAIDS IN BOTSWANA
}

\section{Johanna R Zuyderduin}

DLitt et Phil graduate

Lecturer, Capacity Project/USAID

\section{Valerie J Ehlers}

DLitt et Phil

Professor, Department of Health Studies, University of South Africa, Pretoria

Corresponding author: ehlersjh@mweb.co.za

\section{Dirk M van der Wal \\ DLitt et Phil \\ Senior Lecturer, Department of Health Studies, University of South Africa, Pretoria}

Keywords: adherence to anti-retroviral therapy (ART); anti-retroviral drugs (ARVs); anti-retroviral therapy; buddy; buddy system; CD4 cell counts; HIVIAIDS; immune deficiency; patients (HIV+ve women); people living with AIDS/ HIV (PLWA/H); self-care behaviours

\section{List of abbreviations}

AIDS - Acquired immune deficiency syndrome

ART - Anti-retroviral therapy

ARVs - Anti-retroviral drugs

BWP - Botswana pula

COCEPWA - Coping Centre for People with AIDS

HIV - Human immunodeficiency virus

HIV+ve - Human immunodeficiency virus positive

INH - Isoniazid

MTCT - Mother-to-child transmission

PLWA/H - People living with AIDS/HIV

TB - Tuberculosis

VCT - Voluntary counselling and testing

\section{ABSTRACT}

A needs assessment done among HIV-positive (HIV+ve) people in Botswana in 2000 indicated that these people required social support. Based on these results, a buddy system for and by HIV+ve women was instituted in Botswana during 2002. This study examined the impact of the buddy system on the self-care behaviours of 116 HIV+ve women volunteers who used the services of COCEPWA (Coping Centre for People with Aids) during 2002. The convenience sample comprised 39 buddies who completed the buddy training programme, 39 patients assigned to the 39 buddies and 38 controls who lived in areas where the buddy programme did not operate. The results indicate that HIV+ve patients who had buddies showed improved self-care behaviours from April 2002 until November 2002 compared to the controls. These self-care behaviours encompassed informing a number of other people about their HIV+ve status, compliance with tuberculosis treatment, CD4 quantification and adherence to antiretroviral therapy. Although the differences were not always statistically significant, the patients showed greater improvements than the controls in all self-care behaviours. Thus the buddy system might have assisted and empowered the patients to achieve higher levels of self-care behaviours than the controls. 


\section{OPSOMMING}

'n Behoeftebepaling wat in 2000 van MIV-positiewe (MIV+we) persone in Botswana gedoen is, het getoon dat hierdie mense sosiale ondersteuning nodig gehad het. Gebaseer op hierdie bevindinge is 'n "buddy"-stelsel vir en deur MIV+we vroue gedurende 2002 in die land ingestel. Hierdie studie het die impak van die "buddy"-stelsel op die selfsorggedrag van 116 MIV+we vroulike vrywilligers ondersoek wat die dienste van COCEPWA (Coping Centre for People with AIDS) gedurende 2002 benut het. Die gerieflikheidsteekproef het uit 39 "buddies" bestaan wat die "buddy"-opleidingsprogram voltooi het, 39 pasiënte wat aan die 39 "buddies" toegewys is en 38 kontrolepatiënte wat in areas gewoon het waar die "buddy"-program nog nie in werking gestel is nie. Die bevindinge dui aan dat MIV+we pasiënte wat "buddies" gehad het verbeterde selfsorggedrag van April 2002 tot November 2002 getoon het, in vergelyking met die kontrolegroep. Selfsorggedrag is aangedui deur die aantal ander persone wat ingelig is omtrent die individu se MIV+we status, die nakoming van tuberkulosebehandeling, CD4-bepalings en die nakoming van antiretrovirale behandeling. Alhoewel die verskille nie altyd statisties beduidend was nie, het die pasiënte groter verbeteringe getoon in vergelyking met die kontrolegroep in alle aspekte van selfsorggedrag. Dus is dit moontlik dat die "buddy"-stelsel die pasiënte ondersteun en bemagtig het, wat hulle in staat gestel het om 'n groter mate van selfsorggedrag te bereik as die kontrolegroep.

\section{INTRODUCTION}

During 2004, the Joint United Nations Programme on HIVIAIDS (UNAIDS) reported that globally an estimated 39.4 million people were living with HIVIAIDS, 4.9 million people became newly infected with HIV and 3.1 million people died of AIDS. Sub-Saharan Africa (SSA) is the worst hit region with $60.0 \%$ (25.4 million) of all people living with HIVIAIDS, although SSA has only $10.0 \%$ of the world's population (UNAIDS, 2004a:1). Botswana is a middle-income SSA country with a per capita gross domestic product of US\$3 300 and an estimated sustained growth rate of $9.0 \%$ per annum (UNAIDS, 2004b:1). HIVIAIDS affects $38.8 \%$ of Botswana's economically active population and the prevalence of HIV among pregnant women aged $15-49$ years was $35.4 \%$ during 2000 (NACA, 2002:49; UNDP, 2000:7). These HIVIAIDS statistics imply that an estimated 330000 people were living with HIVIAIDS in Botswana at the end of 2002 (UNAIDS, 2004b:1). Based on the estimated HIV prevalence of $35 \%$ in 2001 , and the hypothesis that approximately $30 \%$ of the HIV positive (HIV+ve) population would have CD4 counts below $200 \mathrm{~mm}^{3}$, and that $10 \%$ of the population with CD4 counts above $200 \mathrm{~mm}^{3}$ would have an AIDS-defining illness, it was estimated that the demand for anti-retroviral therapy (ART) would be about 110000 people in Botswana in 2001 (De Korte, Mazonde \& Darkoh, 2004:2). People who start using anti-retroviral drugs (ARVs) but who fail to adhere to their regimens will not derive the maximum benefits from ARVs, might develop full-blown AIDS, and spread HIV mutations that are resistant to ARVs, putting their sex partners and communities at risk of becoming HIV+ve with ARV-resistant strains. Adherence to ARVs is influenced by cultural traditions and practices as well as by peer group influences and health care workers' attitudes (Ritzenthaler, 2005:1).

The Botswana government has instituted a number of services to address the HIVIAIDS epidemic, including supplying home-based care for terminally ill patients, providing prevention of mother-to-child transmission (MTCT) of HIV as well as voluntary counselling and testing (VCT) services. ARVs have been supplied in Botswana since 2001 (Zuyderduin, 2004:7-8). Botswana's national ART programme is known as the MASA, meaning "a new dawn", programme.

\section{The implementation of a buddy system in Botswana}

Under the auspices of COCEPWA (Coping Centre for People with AIDS), a needs assessment was done among people living with AIDS/HIV (PLWA/H) in Botswana (Zuyderduin, Ehlers \& Van der Wal, 2007:39). The PLWA/H indicated that they were "willing to be involved in care and support efforts and demonstrated their enthusiasm and motivation to support other PLWA/ $\mathrm{H}$ in Botswana" (Zuyderduin et al., 2007:50). Other research reports also indicated that social support is an 
important factor in illness management and a strong predictor of treatment adherence (Aidsmap, 2005:5; Ngamvitroj \& Kang, 2006:2; Lee, Ko \& Lee, 2006:294; Phaladze, Human, Dlamini, Hulela, Hadebe, Sukati, Makoe, Seboni, Moleko \& Holzemer, 2005:122).

Using the results of this Botswana needs assessment, supported by previous research reports emphasising the importance of social support to PLWA/H, $39 \mathrm{HIV}+\mathrm{ve}$ women volunteers were trained as buddies at the beginning of 2002 by COCEPWA. This training included basic HIVIAIDS knowledge, compliance with tuberculosis (TB) treatment, CD4 cell counts, ARV adherence and support skills. The buddies were paid a stipend of BWP50 per month and were expected to devote 4-6 hours weekly to their patients. Buddies were not expected to implement directly observed treatment of their patients' TB pills or ART on a daily basis. However, the buddies had to offer support and guidance about adherence to all treatment regimens. The buddies' strength lay in expressing care and concern for other women living with HIV. That is why the buddy programme stressed the aspect of care and support for and by women living with HIV.

Implementing and sustaining a buddy programme for and by HIV+ve women was an expensive exercise. Thus it became important to determine whether the buddy system had any impact on the self-care behaviours of HIV+ve patients, who were supported by trained buddies.

\section{DEFINITION OF KEY TERMS}

Adherence refers to the "degree to which a patient follows drug schedules; a synonym for compliance; implying a steady propensity to stick to a prescribed therapeutic regimen" (Murphy \& Canales, 2001:176). In this case adherence refers to the patients' compliance with their prescribed ARV and/or TB drug regimens.

Anti-retroviral drugs (ARVs) are pharmacological agents that act on retroviral infections, improving the symptoms, but not curing the disease. ARVs must be taken for the duration of the person's life.

Anti-retroviral therapy (ART) refers to the ARVs prescribed for a specific HIV+ve person.
A buddy refers to a friend or a companion. In this study a buddy was an HIV+ve woman who had successfully completed the buddy training programme and was assigned to tend to a specific HIV+ve woman (patient) in the community.

The buddy system refers to the system implemented by COCEPWA in Botswana, whereby trained buddies are assigned to specific HIV+ve women (patients). Buddies need to provide information and support to their patients.

COCEPWA refers to the Coping Centre for People with AIDS, a non-government organisation in Botswana that trains buddies and provides a social support network to HIV+ve women. (No VCT services are provided by COCEPWA, as these services are available free of charge at government clinics and hospitals in Botswana.)

CD4 cell count is a measure indicating how much the human immunodeficiency virus has diminished a person's immune functions. Normal CD4 values range between 800 and 1200 cells $/ \mathrm{mm}^{3}$ and patients with CD4 cell counts of lower than 200 cells $/ \mathrm{mm}^{3}$ are eligible for free ARVs in Botswana (Zuyderduin, 2004:171).

A patient is someone who uses specific services. In this report the term "patient" refers to an HIV+ve woman who had a specific buddy assigned to her, although the term "client" continues to be used within Botswana and COCEPWA contexts.

HIVIAIDS refers to diseases caused by the retrovirus, of the lentevirus class, with delayed onsets and protracted courses, without any cure (Kalichman, 1995:363).

Immune deficiency refers to a breakdown in parts of the immune system's functions, increasing the person's susceptibility to diseases, especially to TB (Kalichman, 1995:362).

MASA is a Setswana word meaning "new dawn" and is the name of the Botswana government programme providing ARVs and AIDS treatment and care to the people of Botswana. 
People living with AIDS or HIV (PLWA/H) are individuals infected with the human immunodeficiency virus and are thus HIV+ve.

Self-care behaviours refer to behaviours that people "initiate and perform, within time frames, on their own behalf in the interests of maintaining life, healthful functioning, continuing personal development and well-being, through meeting known requisites for functional and developmental regulation" (Orem, 2001:522). In this study HIV+ve women's self-care activities refer specifically to the checking of their CD4 cell counts, using ARVs and completing TB prevention therapy.

\section{PURPOSE, OBJECTIVES, ASSUMPTIONS AND HYPOTHESIS OF THE STUDY}

The purpose of this study was to determine whether the buddy system would impact positively on the selfcare behaviours of HIV+ve women in Botswana. In order to identify these potential differences, data was gathered prior to the implementation of the buddy system (during April 2002) and again six months later (during November 2002) from 39 buddies, 39 patients and 38 controls. The specific self-care behaviours that were investigated included disclosure of HIV+ve status to others, periodic CD4 quantifications, compliance with TB treatment/prophylaxis and adhering to ARVs.

The objectives of the study were to:

- identify the number of people to whom the participants had disclosed their HIV+ve status during April and November 2002;

- monitor the CD4 quantifications during April and November 2002;

- obtain HIV+ve women's self-reports about their compliance with TB treatment or prophylaxis during April and November 2002;

- determine whether the HIV+ve women adhered to their ART; and

- identify whether differences in these behaviours occurred between the buddies, patients and controls from April 2002 to November 2002.

The major assumption underlying this study was that the buddy system would impact positively on the selfcare behaviours of the patients. This was expected owing to the support and guidance the patients would have received from their buddies over a six-month pe- riod compared to the controls, who had no buddies. No major changes were expected in the behaviours of the buddies as they had been trained as buddies from the outset of the study. Including a control group excluded the possibility that changes in patients' self-care behaviours could be attributed to the time lapse of six months only and not necessarily to the buddies' interventions in their patients' self-care behaviours.

The hypothesis guiding this quasi-experimental design was that there would be significant changes in the patients' self-care behaviours from April to November 2002 compared with those of the controls.

The null hypothesis underlying the study was that there would be no significant changes in the patients' selfcare behaviours from April to November 2002 compared with those of the controls.

\section{ETHICAL CONSIDERATIONS}

The ethical issues pertinent to this study related to the fact that individual participants should not be harmed by the conduct, publicity and/or results of the research. The research proposal was approved by the Research and Ethics Committee of the Department of Health Studies, Unisa. COCEPWA was fully informed of the nature and purpose of the research project, and monthly discussions were held with COCEPWA members throughout the data collection period.

Every willing participant signed a consent form, which was sealed in an envelope and placed in a container, separate from the container used for the anonymously completed structured interview schedules. In this way no signed consent form could be linked to any specific completed structured interview schedule, ensuring anonymity. The participants were assured that they would remain entitled to the health care services whether or not they participated in the research project, and that they could withdraw their participation at any stage without suffering any ill effects whatsoever. Every participant's level of HIV disclosure was respected. Each buddy signed a written agreement about her rights and responsibilities. A COCEPWA supervisor monitored the buddy-patient pairs and a telephone line was available for handling any queries.

No names were entered on the structured interview 
schedule. Each participant was assigned a unique number for later correlation of the two sets of data, obtained during April and November 2002. This information was kept locked up and available only to one researcher until its destruction after the approval of the research report.

\section{RESEARCH DESIGN AND METHODS}

A quasi-experimental descriptive survey was used to explore the impact of the buddy system on the selfcare behaviours of HIV+ve women in Botswana.

\section{Population and sample}

Only 39 women volunteered to be trained as buddies. COCEPWA's policy is to assign only female patients to female buddies. Thus the population for this study comprised all HIV+ve women in Botswana. However, this population is unknown and invisible, without any existing census of these women. Each HIV+ve COCEPWA member was approached to participate in the study and to invite any other HIV+ve woman to participate, amounting to snowball sampling. All participants had to be older than 18 , able to sign consent to participate in the study, and had to have disclosed their HIV+ve status to at least one other person.

During 2002, when the data was collected, the buddy programme was available only in selected towns in Botswana. Of the 116 participants, 39 volunteered to be trained as buddies, who were willing to be disclosed as being HIV+ve women. Subsequent to completing her training, each buddy was paired with a patient. The other 38 women were assigned to the control group, being neither buddies nor patients. Thus the sample comprised 116 women (39 buddies, 39 patients and 38 controls) in April 2002 but only 111 in November 2002 because five women died during this time. Four of the women who died used ARVs and one did not.

\section{Research instrument}

Initially it was the intention to use a questionnaire to collect data as it could be completed in total privacy, ensuring the anonymity of the respondents (Breakwell, Hammond \& Fife-Schaw, 2000:161). However, during the pretest phase, all the women requested the research assistant to remain nearby and to elaborate on some questions. The research assistants ended up entering the women's responses on the questionnaires as they were familiar with the questionnaire's layout. This amounted to conducting structured interviews. Every structured interview commenced by asking demographic questions, enabling the interviewer and the participant to become familiar with each other and facilitating the rest of the interview process.

The structured interview schedule, using Likert scales, comprised seven items requesting information about demographics and self-care behaviours. The items were selected based on a literature review, and on the four self-care behaviours selected for this study, namely disclosure of HIV+ve status to others, adherence to TB and $A R V$ regimes and having CD4 cell counts done at regular intervals.

\section{Validity and reliability}

Validity refers to the extent to which an instrument "actually reflects the abstract construct being measured" (Burns \& Grove, 2001:814). The employees of COCEPWA agreed that the items included in the structured interview schedule requested information about the interviewees' demographics, or their self-care behaviours relevant to disclosure of HIV+ve status, adhering to ART and/or TB treatment and having regular checks done of CD4 counts. Two researchers and a statistician also examined the structured interview schedule's items and declared that every item was relevant to self-care behaviours of HIV+ve women. During pretesting the instrument, the HIV+ve women requested that the English terminology be included in addition to the Setswana terminology. This was done to enhance the women's understanding of each question.

Reliability refers to the consistency with which an instrument measures a specific construct (Burns \& Grove, 2001:809). The same structured interview schedule was used during the pretest before the actual data collection commenced, prior to the interaction of buddies and patients in April 2002, and again six months into the buddy-patient relationships in November 2002. The scores obtained for the four different types of self-care behaviours did not change significantly for the buddies and controls over the six-month period, although many scores changed for the patients. Thus the structured interview schedule was stable over the six-month pe- 
riod. Four trained interviewers conducted the structured interviews. The completed structured interview schedules were checked on a daily basis by the first author for completeness and accuracy of reported data. No differences could be attributed to specific interviewers, and therefore the instrument was assumed to have had inter-rater reliability.

The Kruskal-Wallis test is the most powerful non-parametric test for detecting differences between three or more groups (Burns \& Grove, 2001:579, 589). The Kruskal-Wallis test results indicated that there were differences between the buddies, patients and controls in this study (Zuyderduin, 2004:Annexure VI), confirming the structured interview schedule's reliability.

\section{Data collection process}

The structured interview schedule was translated into Setswana. Four structured interviews were conducted with COCEPWA volunteers to pretest the instrument. It took 45 minutes to conduct one interview and to write down the verbatim responses. The major recommendation of the women who participated in the pretest was that the English terms for HIVIAIDS issues also be included, as these were better known to respondents than the Setswana terms. This was done.

Four research assistants, COCEPWA employees who were bilingual in English and Setswana, knowledgeable about HIVIAIDS and known to the COCEPWA patients, were trained to conduct the structured interviews. These interviews were conducted with the buddies, patients and controls during April 2002, prior to the assignment of buddies to patients, in order to gather baseline data, and again in November 2002, six months after the buddy-patient pairs had been established. The interviews were conducted at a time convenient for each participant in a private room at COCEPWA, as visits from COCEPWA staff members at patients' homes might have indicated their HIV+ve status to their family members, friends and/or neighbours. No interviewee agreed to being audiotaped. The first author checked every completed structured interview schedule immediately after its completion and any ambiguities were clarified with the interviewer and/or interviewee.
The answers recorded on the structured interview schedules were transposed as numbers to allow for a computer-based analysis, using the Statistical Package for the Social Sciences (SPSS) version 12, with the help of a statistician. The variables of interest were the scores of the buddies, patients and controls at baseline in April 2002, and six months later in November 2002, specifically pertaining to the disclosure of their HIV+ve status, the adherence to TB and ART regimens, and the testing of CD4 cell counts.

\section{RESEARCH RESULTS}

\section{Demographic information}

The ages of the 116 women ranged from 20 to 52 with an average age of 31.16 years (SD 7.18). The average age of the buddies was three years higher than that of the patients and controls. Of the participants, only $13.8 \%(n=16)$ were married, $3.4 \%(n=4)$ were widows, while $25.9 \%(n=30)$ were single and $56.9 \%(n=66)$ were unmarried but had partners. The number of children that the HIV+ve women had varied between 0 and $6(\mathrm{M}=1.85$, $\mathrm{SD}=1.37)$. Twenty-six HIV+ve women had attended at least primary school (22.4\%; n=116) and 56 (48.3\%) had secondary school education up to Junior Certificate level, which is equivalent to three years of secondary schooling. Twenty-one HIV+ve women (18.1\%) had completed their secondary education up to $\mathrm{O}$ Level (ordinary or school end certificate level). Post-secondary education, college or vocational training had been achieved by 11 (9.5\%) HIV+ve women, and 2 (1.7\%) $\mathrm{HIV}+\mathrm{ve}$ women had been to university.

Of the 116 women, 38 (32.8\%) were employed full time, $1(0.9 \%)$ was a student and $22(19 \%)$ were volunteer workers. As many as 55 (47.4\%) HIV+ve women were not employed.

In April 2002, 67 HIV+ve women (57.8\%; n=116) earned less than BWP200 per month. The patients seemed less well off, with nobody in this group earning more than BWP1 500 and 24 (60.5\%) patients earning BWP200 or less.

\section{HIV+ve women's self-care behaviours}

To explore the self-care behaviours before the patients had been linked up with their buddies and to assess 
whether self-care behaviours improved six months into the buddy relationship, questions were asked about HIV testing and disclosure of positive results to others, compliance with TB treatment, CD4 cell count quantifications and adherence to ART.

\section{Disclosure of HIV positive test results}

The HIV+ve women were asked to state the number of people to whom they had disclosed their HIV+ve status in April 2002 and again in November 2002.

By April 2002, of the 116 HIV+ve women, 50\% ( $n=58)$ had disclosed their HIV+ve status to between 1 and 5 people and $17.2 \%(n=20)$ had disclosed to 31 or more people. More buddies had disclosed to more people than the other groups because 11 buddies (28.2\%) had disclosed to 31 or more people.

There was an increase in the number of people to whom the participants' HIV+ve status had been disclosed after six months; the frequency of the lowest category (1 to 5) was only $24.3 \%(n=27)$, and the frequency of the highest category (31 or more) had increased from $17.1 \%$ $(n=19)$ to $30.6 \%(n=34)$.

The buddies were more open about their HIV+ve status than the controls and the patients in April 2002. Over the six-month period, 17 of the 34 buddies (50\%) remained in the same category, but the other 17 buddies (50\%) moved to a higher category, meaning that they had disclosed their status to substantially more people by November 2002.
Of the 38 controls, 42.1\% $(n=16)$ had disclosed their HIV+ve status to 1 to 5 people, $60.5 \%(n=23)$ remained in the same category and $39.5 \%(n=15)$ moved to a higher category, having disclosed their HIV+ve status to more people by November 2002.

The 39 patients' disclosure levels also increased, with $48.7 \%(n=19)$ moving to a higher category and $51.3 \%$ $(n=20)$ remaining in the same category. The controls and patients still had more participants in the 1 to 5 group than the buddies, and fewer in the group of 31 or more people.

The Pearson chi-square test (value 17.168; $p=.009$, twosided) was used to compare the three groups' disclosure status. The difference was significant at the $1 \%$ level of significance. The buddies and the patients were more open about disclosing their HIV+ve status to others between the first and second surveys than the controls, with fewer buddies and patients having told five or fewer people compared to the controls. Having a buddy resulted in increased levels of disclosure for $51.3 \%$ $(n=20)$ of the patients. Not having a buddy did not prevent the controls from disclosing their HIV+ve status to more people, but they did so at a slower pace than the patients.

These results suggest that participating in the buddy system encouraged disclosure of HIV+ve status to other people, but did not force the HIV+ve women to disclose if they were not ready to do so. It can be accepted that the buddy system impacted positively on the number of people the women informed about their

Table 1: Number of people to whom buddies, patients and controls had disclosed their HIV+ve status by April $2002(\mathrm{~N}=116)$

\begin{tabular}{|l|l|l|l|l|l|l|l|l|}
\hline $\begin{array}{l}\text { No. of } \\
\text { people dis- } \\
\text { closed to }\end{array}$ & \multicolumn{3}{|l|}{ Buddies } & \multicolumn{2}{l|}{ Patients } & \multicolumn{2}{l|}{ Controls } & \multicolumn{2}{l|}{} \\
\hline & $\mathrm{n}$ & $\%$ & $\mathrm{n}$ & $\%$ & $\mathrm{n}$ & $\%$ & $\mathrm{n}$ & $\%$ \\
\hline $1-5$ & 11 & 28.2 & 21 & 53.8 & 26 & 68.4 & 58 & 50.0 \\
\hline $6-10$ & 8 & 20.5 & 6 & 15.4 & 4 & 10.5 & 18 & 15.5 \\
\hline $11-30$ & 9 & 23.1 & 9 & 23.1 & 2 & 5.3 & 20 & 17.2 \\
\hline 31 or more & 11 & 28.2 & 3 & 7.7 & 6 & 15.8 & 20 & 17.2 \\
\hline Total & 39 & & 39 & & 38 & & 116 & \\
\hline
\end{tabular}


HIV+ve status. Nevertheless, HIV+ve people in Botswana might not disclose their HIV+ve status to their loved ones and families because they might want to protect them from hearing such bad news, or because they want to protect themselves from being blamed for bringing AIDS into their homes (Tlou, 2002:655).

\section{TB treatment compliance}

Prevention of TB is promoted within Botswana's health care system. All HIV+ve people are tested for TB and, if positive, they are put onto TB treatment. If they test negative, they are put on TB prophylaxis. This is done to address the potential development of $T B$, which is the most common opportunistic infection of PLWA/H in Botswana, accounting for $30 \%$ to $40 \%$ of all AIDS related deaths (NACA, 2003:44). The present study asked the HIV+ve women if they were suffering from TB and, if so, whether they were being treated. If the HIV+ve women were not suffering from TB, the next question was whether they had completed or were taking Isoniazid preventive treatment.

The HIV+ve women were classified into "low level of self-care behaviours" and "high level of self-care behaviours" with regard to TB. If they were taking or had completed a six-month course of Isoniazid (INH) to prevent latent TB from becoming active TB, or were on treatment for their acute TB infection, they were displaying a "high level of self-care behaviours" for TB. If they were not taking or had never completed a six-month course of INH to prevent latent TB from becoming active TB, or if they did not adhere to their TB treatment regimes, they were classified as "low levels of self-care behaviours" for TB.
During April 2002, of the 116 HIV+ve women, 12 (10.3\%) had active TB. Of these 12 women, no one was a control but 8 were buddies and 4 were patients. All $12 \mathrm{HIV}+\mathrm{ve}$ women were on treatment to cure TB. Out of the total group of 116 HIV+ve women, 7 (17.9\%) buddies practised high levels of self-care behaviours, compared with $13(34.2 \%)$ controls and 11 (28.9\%) patients. The differences between the three groups and levels of selfcare behaviours were not significant at the $5 \%$ level of significance $(p=0.293)$ as revealed by the baseline data.

During November 2002, the number of HIV+ve women who practised high levels of self-care behaviours was 15 (44.1\%) buddies, 19 (50.0\%) controls and 16 (41.0\%) patients. The difference was not significant ( $p=.707)$. Nine buddies (26.4\%), 6 controls (15.8\%) and 5 patients $(12.8 \%)$ changed from low to high levels of selfcare behaviours between the two surveys. These differences were not significant at the $5 \%$ level of significance $(p=.381)$.

Thus it can be concluded that being or having a buddy had no significant impact on the HIV+ve women's selfcare behaviours concerning TB treatment and prophylaxis.

Adherence to treatment or prophylaxis for TB is vital for the HIV+ve person's health and wellbeing. This is the case because TB is reportedly the leading cause of death among HIV+ve people, as more than $30 \%$ of HIV+ve people die as a result of TB (Clemens, 2003:97). As the buddies enhanced the patients' adherence to TB treatment and prophylaxis, they could play a major role in decreasing the mortality and morbidity rates from

Table 2: Number of buddies, patients and controls practising high levels of TB self-care

\begin{tabular}{|l|l|l|l|l|l|l|}
\hline $\begin{array}{l}\text { High levels } \\
\text { of TB self- } \\
\text { care }\end{array}$ & $\begin{array}{l}\text { Buddies } \\
\text { (n=39 April; } \\
\mathbf{n = 3 4} \text { Nov) }\end{array}$ & \multicolumn{2}{l|}{$\begin{array}{l}\text { Patients } \\
(\mathbf{n}=39)\end{array}$} & \multicolumn{2}{l|}{$\begin{array}{l}\text { Controls } \\
(\mathbf{n}=38)\end{array}$} \\
\hline & $\mathrm{n}$ & $\%$ & $\mathrm{n}$ & $\%$ & $\mathrm{n}$ & $\%$ \\
\hline April 2002 & 7 & 17.9 & 11 & 28.2 & 13 & 34.2 \\
\hline Nov 2002 & 15 & 44.1 & 16 & 41.0 & 19 & 50.0 \\
\hline
\end{tabular}


Table 3: Number of buddies, patients and controls who had regular CD4 checks during April 2002 $(\mathrm{N}=116)$ and November $2002(\mathrm{~N}=111)$

\begin{tabular}{|l|l|l|l|l|l|l|l|l|}
\hline $\begin{array}{l}\text { CD4 } \\
\text { checks } \\
\text { done }\end{array}$ & $\begin{array}{l}\text { Buddies } \\
\text { (n=39 April; } \\
\text { n=34 Nov) }\end{array}$ & $\begin{array}{l}\text { Patients } \\
\text { n=39 }\end{array}$ & $\begin{array}{l}\text { Controls } \\
\text { n=38 }\end{array}$ & \multicolumn{3}{|l|}{$\begin{array}{l}\text { Total } \\
\text { (N=116 April; } \\
\text { N=111 Nov) }\end{array}$} \\
\hline & $\mathrm{n}$ & $\%$ & $\mathrm{n}$ & $\%$ & $\mathrm{n}$ & $\%$ & $\mathrm{n}$ & $\%$ \\
\hline April 2002 & 29 & 74.4 & 19 & 48.7 & 18 & 47.4 & 66 & 56.9 \\
\hline Nov 2002 & 30 & 88.2 & 35 & 89.7 & 27 & 71.1 & 92 & 82.1 \\
\hline
\end{tabular}

TB for HIV+ve people.

\section{CD4 quantification}

At the start of the study in April 2002, 66 (56.9\%) out of the $116 \mathrm{HIV}+\mathrm{ve}$ women had checked their CD4 counts regularly and $50(43.1 \%)$ had not done so. Of the 66 women who had checked their CD4 counts, 29 (74.4\%) were buddies, 18 (47.4\%) were controls and 19 (48.7\%) were patients. This difference was significant at the $5 \%$ level of significance $(p=0.026)$.

The responses in November 2002 indicated that CD4 count checks had increased in all three groups from $56.9 \%(n=66)$ to $82.1 \%(n=92)$, but the patients $(89.7 \%$; $\mathrm{n}=35)$ and buddies (88.2\%; $\mathrm{n}=30$ ) exceeded the controls $(71.1 \% ; n=27)$. In total, 92 out of $111(82.1 \%)$ HIV+ve women checked their CD4 counts regularly and 19 (16.9\%) did not do so by November 2002. The increase in the percentage of patients who checked their CD4 counts regularly was $80 \%$ (increased from 19 to 35 out of 39) patients but for the controls it was only $45 \%$ (increased from 18 to 27 controls out of 38) (Zuyderduin, 2004:229). The chi-square test provided no significant differences at the $5 \%$ level of significance $(p=0.227)$.

It can be concluded that more patients than controls had CD4 counts done, although this difference was not statistically significant. Therefore it cannot be concluded that the buddy system necessarily impacted positively on the number of HIV+ve women who had regular CD4 counts done.

The optimum time to commence ART is before patients present with opportunistic infections or become generally unwell. A baseline CD4 count, when the person is diagnosed as HIV+ve, is essential for future compari- sons to judge the progress of the disease and the decline of the person's immune system. Patients with CD 4 counts below 200 cells $/ \mathrm{mm}^{3}$ or with AIDS-defining illnesses should be started on ART (WHO, 2006:16). Whether the HIV+ve person is on ART or not, it remains essential to have regular CD4 counts done to monitor the progress of the disease or the patient's reaction to ART (Anabwani \& Jimbo, 2005:6-7). Thus it remains vital that every PLWA/H has regular CD4 cell counts done. Buddies can play an important part in reminding their patients to go for regular tests, to support them before, during and after the tests and to act appropriately once the CD4 results are known.

\section{Adherence to ART}

A higher percentage of the buddies, namely 17 (43.6\%), took ARVs in April 2002 than the other two groups. Only 7 (18.4\%) controls and 11 (28.2\%) patients took ARVs. In total, 35 (30.2\%) HIV+ve women were taking ARVs in April 2002 and 81 (69.8\%) were not. The responses in November 2002 indicated that both the patient and control groups' numbers had increased: the patients increased to $48.7 \%(n=19)$; the controls increased to $36.8 \%(n=14)$, but the actual number of controls going on ARVs had doubled from 7 to 14 . This difference is not significant at the $5 \%$ level of significance $(p=0.453)$.

The majority of HIV+ve women, $68.6 \%(n=35)$, who took ARVs had been doing so for 6 months or less. Nine HIV+ve women (25.7\%) had been on ARV treatment for 7 to 12 months and two (5.7\%) of the HIV+ve women had been taking ARVs for periods ranging from 13 to 24 months. In terms of status groups, the frequencies were that the 17 buddies had been taking ARVs for longer than controls and patients. Five controls had taken ARVs for 6 months or less. Only one patient and 
one buddy had taken ARVs for longer than a year. Six months later, of the $111 \mathrm{HIV}+\mathrm{ve}$ women, 51 (46.0\%) were taking ARVs. The 7 to 12 months category had the highest frequency, with 22 (43.1\%) of the $51 \mathrm{HIV}+\mathrm{ve}$ women, followed by 19 (37.3\%) who had been on ARVs for 6 months or less, and 10 (19.6\%) who had been using ARVs for between 13 and 24 months. The buddies and patients reported the 7 to 12 months category as the highest frequency, but in the controls 0 to 6 months had the highest frequency. The buddies had the highest prevalence of being on ARVs for between 13 and 24 months.

The level of self-care behaviours regarding ARVs was high at the outset for the 29 buddies. The buddies had a higher level of self-care regarding ARVs than the patients, only 15 of whom had a high level to begin with in April 2002. The difference between the three groups was significant $(p=0.049)$. Six months later only one more buddy had been added to the high group, bringing the total to 30 buddies. However, for the patients, 20 changed from low to high levels of self-care behaviours, bringing the total to 35 patients. These differences were significant at the $5 \%$ level $(p=0.041)$. By November 2002 nearly $90 \%$ of both groups had reached the desired high levels of self-care behaviours. This was a significant improvement and an indication that the buddies had been successful in moving their patients from low to high levels of self-care behaviours for ARVs.

By November 2002, 80\% ( $n=93$ ) of the 116 HIV+ve women had been seen by a medical doctor to discuss their CD4 quantification results at three- or six-monthly intervals during 2002. This was a 30\% increase from April 2002. The total number of buddies (88.2\%; $n=30)$ and patients (89.7\%; $n=35$ ) who had checked their CD4 counts and gone onto ARV therapy when they needed to was almost $90 \%$ in each group by November 2002 , compared to $71.1 \%(n=27)$ of the controls who remained at or reached high levels of self-care behaviours for ARV. The buddy system seemed effective in enhancing selfcare behaviours for ARVs.

Botswana's ART guidelines (MoH, 2000:3) aim to improve the health of PLWA/H by slowing down the progression of the disease through providing cost-effective ART, reduce the transmission of HIV and minimise HIV drug resistance in the Botswana communities (Kip, 2007:11). The major barrier to ART adherence was re- portedly forgetfulness in Maun in Botswana $(\mathrm{MoH}$, 2005:2). Buddies could thus play a major role in enhancing their patients' ART adherence levels by merely reminding the patients to renew their ART.

\section{LIMITATIONS}

All the participants were HIV+ve Botswana women aged 18 years or older who were members of COCEPWA. Different results might have been obtained by studying a cross-section of the population of both sexes and different ages, and of people who were not COCEPWA members (but these constituted an "invisible population" during the data collection phase of this study). There are no guarantees that the 116 women who volunteered to participate represented all women living with HIV in Botswana, because of the non-random (snowball) sampling method used. HIV+ve women who had not disclosed their status to others might have had different types of self-care behaviours which remained unidentified during this study.

Two possible mistakes might have been made concerning the null hypothesis: rejecting a true null hypothesis, or accepting a false null hypothesis because the sample size of 116 was small and because the probability level of .10 implied that there was a $10.0 \%$ risk of committing one of these errors (Burns \& Grove, 2001:815). These statistical considerations prevent the generalisation of the research results to the population of HIV+ve women in Botswana.

Different results might have been obtained by conducting in-depth qualitative interviews, but none of the HIV+ve women who participated in this study would have agreed to being tape-recorded. Focus group interviews were out of the question as this would have implied disclosing respondents' HIV+ve status to every participant in the focus group.

Interviewing other relevant people to validate each interviewee's report could have validated the research results. However, this was not done as such interviews with 'significant others' carried the risk of involuntary disclosure of the specific woman's HIV+ve status. This would have amounted to a breach of confidentiality, and was therefore not attempted.

Checking the women's verbal reports against their clini- 
cal data on their medical files could also have increased the validity of the findings, using triangulation of data sources. However, this could not be done as each woman interviewed was assured of anonymity and confidentiality. Rigorous steps need to be followed to obtain permission for using data on patients' files from Botswana's Medical Research Council. Such permission was not obtained for this study, and patients' files could thus not be used.

\section{CONCLUSIONS}

Based on the research results, the null hypothesis that the implementation of the buddy system had no impact on the self-care behaviours of patients was rejected. The hypothesis that the implementation of a buddy system improved patients' self-care behaviours of disclosing their HIV+ve status, adhering to TB treatment/prophylaxis, having regular CD4 counts done and adhering to ART was accepted at the .10 significance level.

The buddy system translated theory into practice. By practising additional self-care behaviours, the HIV+ve women were able to participate more actively in shaping the conditions that influenced their health. The results of increased levels of disclosure, increased checks of CD4 counts and enhanced levels of self-care behaviours for TB and ARVs in the present study pointed towards the effectiveness of being a buddy and having a buddy to promote levels of self-care behaviours and possibly also enhanced levels of personal wellbeing.

\section{RECOMMENDATIONS}

HIV+ve women who adhere to their ART, and who are willing to disclose their HIV+ve status, should be recruited and trained to become buddies to other PLWA/ $\mathrm{H}$ in Botswana. Trained buddies should participate in the training of future buddies.

A longitudinal study should be conducted to monitor the potential impact of the buddy system on the selfcare behaviours of HIV+ve patients in Botswana. Based on these results, ongoing education and training should be provided to current and future buddies.

Longitudinal HIV-related quality of life studies should be conducted over a number of years. Although ART can retard the disease progression and extend the patient's life, ART also has unpleasant side effects that could potentially erode the PLWA/H's quality of life. If effective remedies for specific unpleasant side effects could be substantiated by well-documented research, these remedies might enhance the person's quality of life, lengthened by ART.

Future policy planners should consult PLWA/H, and especially trained buddies, about these people's needs.

Future research should focus on the consequences of telling people about their HIV+ve status in Botswana and on ways in which PLWA/H in Botswana cope with the double stigma of being HIV+ve and suffering from TB.

Research-based ongoing community education should be conducted in Botswana informing people about HIV/ AIDS and TB.

\section{CONCLUDING REMARKS}

The buddies, as members of their communities, are role models of positive living and have the skills to motivate their peers to be self-reliant and access HIV care services, when required. "While the challenges are great, the buddy system of care and support for and by women living with HIV or AIDS has a future in a resource-limited country searching for culturally appropriate ways to reach the community with informational and emotional support" (Zuyderduin, 2004:306).

\section{REFERENCES}

AIDSMAP 2005: Treatment and care report. Predicting the nonadherent patient. http://www.aidsmap.com/en/docs/6DBF799A2318-4895-9951-F67A0A6B94E2.asp (Accessed on 17 March 2005).

ANABWANI, G \& JIMBO, W 2005: Botswana: Guidelines on antiretroviral treatment (revised version). Gaborone: Ministry of Health.

BREAKWELL, GM; HAMMOND, S \& FIFE-SCHAW, C 2000: Research methods in psychology; $2^{\text {nd }}$ edition. London: Sage.

BURNS, N \& GROVE, SK 2001: The practice of nursing research: Conduct, critique and utilization; $4^{\text {th }}$ edition. Philadelphia: WB Saunders.

CLEMENS, KE 2003: The foundation of a medical faculty at the University of Namibia. Journal of Pain and Symptom Man- 
agement, 25(2):97-99.

DE KORTE, D; MAZONDE, P \& DARKOH, E 2004: Introducing ARV therapy in the public sector in Botswana. Perspectives and practices in antiretroviral treatment. Geneva: WHO. http:// www.achap.org/downloads/DonaldWHOARV Botswana.pdf (Accessed on 3 June 2005).

JOINT UNITED NATIONS PROGRAMME ON HIVIAIDS 2004a: UNAIDS fact sheet: Sub-Saharan Africa, regional HIV and AIDS estimates end 2004. http://www.unaids.org/en/ geographical+area/by+region/sub-saharan+africa.asp (Accessed on 29 May 2005).

JOINT UNITED NATIONS PROGRAMME ON HIVIAIDS 2004b: UNAIDS country HIVIAIDS estimates, 2003 - Botswana. http:// www.unaids.org/en/geographical+area/by+country/ botswana.asp (Accessed on 7 June 2005).

KALICHMAN, SC 1995: Understanding AIDS: A guide for mental health professionals. Washington DC: American Psychology Association.

KIP, E 2007: Factors influencing patients' adherence to antiretroviral therapy in four selected health facilities in Botswana. Pretoria: University of South Africa (Unpublished DLitt et Phil thesis).

LEE, TW; KO, IS \& LEE, KJ 2006: Health promotion behaviours and quality of life among community dwelling elderly in Korea: A crosssectional survey. International Journal of Nursing Studies, 43(3):293-300.

MINISTRY OF HEALTH (of Botswana) 2000: Botswana guidelines on antiretroviral treatment. Gaborone.

MINISTRY OF HEALTH (of Botswana) 2005: Antiretroviral therapy site update. (MASA pamphlet 17: October 2005). Gaborone.

$\mathrm{MoH}$ See Ministry of Health (of Botswana).

MURPHY, N \& CANALES, M 2001: A critical analysis of compliance. Nursing Inquiry, 8(3):173-181.

NACA See National AIDS Coordinating Agency (of Botswana). NATIONAL AIDS COORDINATING AGENCY (of Botswana) 2003: Status of the 2002 national response to the UNGASS declaration of commitment on HIVIAIDS. Gaborone: Ministry of State President.

NATIONAL AIDS COORDINATING AGENCY (of Botswana) 2002: Botswana 2002 second generation HIVIAIDS surveillance. Technical Report. Gaborone: Ministry of State President.

NGAMVITROJ, A \& KANG, DH 2006: Effects of self-efficacy, social support on adherence to PEFR self-monitoring among adults with asthma: A prospective repeated measures study. International Journal of Nursing Studies, 44(6):882-892.

OREM, DE 2001: Nursing: Concepts and practice; $6^{\text {th }}$ edition. St Louis: CV Mosby.

PHALADZE, NA; HUMAN, S; DLAMINI, SB; HULELA, EB; HADEBE, IM; SUKATI, NA; MAKOE, LN; SEBONI, NM; MOLEKO, M \& HOLZEMER, WL 2005: Quality of life and the concept of "living well" with HIVIAIDS in Sub-Saharan Africa. Journal of Nursing Scholarship, 37(2):120-126.

RITZENTHALER, R 2005: Delivering antiretroviral therapy in resource-constrained settings. Lessons learned from Ghana, Kenya and Rwanda. Implementing AIDS Prevention Care Project. Arlington: Family Health International.

TLOU, SD 2002: Gender and HIVIAIDS. (In Essex, M; Mboup, S; Kanki, PJ; Malink, RG \& Tlou, SD. 2002: AIDS in Africa; $2^{\text {nd }}$ edition. New York: Kluwer Academic, pp 654-663).

UNAIDS See Joint United Nations Programme on HIVIAIDS.

UNDP See United Nations Development Programme.

UNITED NATIONS DEVELOPMENT PROGRAMME 2000: An impact assessment of HIVIAIDS on current and future population characteristics and demographics in Botswana. Gaborone.

WHO See World Health Organization.

WORLD HEALTH ORGANIZATION 2006: Antiretroviral therapy for HIV infection in adults and adolescents in resource-limited settings: Towards universal access. Recommendations for a public health approach. Geneva.

ZUYDERDUIN, JR 2004: The buddy system of care and support for and by women living with HIVIAIDS in Botswana. Pretoria: University of South Africa (Unpublished DLitt et Phil thesis). ZUYDERDUIN, JR; EHLERS, VJ \& VAN DER WAL, DM 2007: People living with AIDS/HIV in Botswana: A needs assessment. Curationis, 30(3):39-51. 